\title{
FACTORS ASSOCIATED WITH LATE DETECTION OF BREAST CANCER IN SURAKARTA, CENTRAL JAVA: APPLICATION OF HEALTH BELIEF MODEL
}

\author{
Wayan Watii), Ambar Mudigdo'), Isna Qadrijati²) \\ 1)Masters Program in Public Health, Universitas Sebelas Maret \\ 2)Faculty of Medicine, Universitas Sebelas Maret
}

\begin{abstract}
Background: Primary prevention of breast cancer is still not available, so efforts to promote early detection continue to be the major focus in fighting breast cancer. Since early detection is associated with decreased mortality, it is important to minimize delays in detection and diagnosis. The purpose of this study was to examine factors associated with late detection of breast cancer in Surakarta, Central Java, using Health Belief Model.

Subjects and Method: A cross sectional study was carried out at Dr. Moewardi Hospital, Surakarta, from October to December 2018. A sample of 200 breast cancer patients was selected by fixed disease sampling. The dependent variable was late detection of breast cancer. The independent variables were perceived susceptibility, threat, benefit, barrier, self-efficacy, family support, breast cancer detection, and family income. The data were collected by questionnaire and analyzed by a multiple logistic regression.

Results: Late detection of breast cancer decreased with perceived susceptibility (b= $1.49 ; 95 \% \mathrm{CI}=-2.55$ to $-0.42 ; \mathrm{p}=0.006)$, perceived threat $\mathrm{b}=-1.87 ; 95 \% \mathrm{CI}=-3.05$ to $0.69 ; \mathrm{p}=0.002)$, perceived benefit $(\mathrm{b}=-3.27 ; 95 \% \mathrm{CI}=-4.54$ to $-2.00 ; \mathrm{p}<0.001)$, selfefficacy $(b=-1.49 ; 95 \% C I=-2.52$ to $-0.46 ; p=0.004)$, family support $(b=-1.44 ; 95 \%$ $\mathrm{CI}=-2.49$ to $-0.39 ; \mathrm{p}=0.007)$, early breast cancer detection $(\mathrm{b}=-2.21 ; 95 \% \mathrm{CI}=-3.33$ to -1.09; $\mathrm{p}<0.001)$, and income $(\mathrm{b}=-1.75 ; 95 \% \mathrm{CI}=-2.92$ to $-0.59 ; \mathrm{p}=0.003)$. It increased with perceived barrier $(b=1.64 ; 95 \% \mathrm{CI}=0.49$ to $2.80 ; \mathrm{p}=0.005)$.

Conclusion: Late detection of breast cancer decreases with perceived susceptibility, perceived threat, perceived benefit, self-efficacy, family support, early breast cancer detection, and income. It increases with perceived barrier.
\end{abstract}

Keywords: late detection, breast cancer, Health Belief Model

\section{Correspondence:}

Wayan Wati. Masters Program in Public Health, Universitas Sebelas Maret. Jl. Ir. Sutami 36A, Surakarta 57126, Central Java, Indonesia. Email: wayanwati99@gmail.com.

Mobile: +6285842842990 . 